\title{
AKIBAT HUKUM GAGALNYA KEBERANGKATAN HAJI YANG DILAKUKAN OLEH PT. DJAHIDIN UNIVERSAL TOUR (DUT) BERDASARKAN UNDANG-UNDANG NO. 13 TAHUN 2008 TENTANG PENYELENGGARAAN IBADAH HAJI DIHUBUNGKAN DENGAN BUKU III KUH PERDATA
}

\author{
Raden Noorman Dermawan \\ Pascasarjana Universitas Islam Bandung \\ RadenNoormanDermawan@gmail.com
}

\begin{abstract}
Abstrak- Gagalnya pemberangkatan calon jemaah haji berkenaan dengan tidak dipenuhinya kewajiban oleh biro perjalanan haji khusus merupakan salah satu bentuk wanprestasi, sebagaimana penyelenggaraan perjalanan haji khusus oleh PT. Djahidin Universal Tour yang gagal memberangkatkan calon jemaah haji harus bertanggungjawab mengganti kerugian akibat kegagalan pemberangkatan calon jemaah haji dan upaya hukum yang dapat dilakukan oleh calon jemaah haji atas gagalnya keberangkatan haji oleh PT. Djahidin Universal Tour berdasarkan Undang-Undang Nomor 13 Tahun 2008 tentang Penyelenggaraan Ibadah Haji dihubungkan dengan Buku III KUH Perdata.Tujuan penelitian ini adalah untuk memahami akibat hukum gagalnya keberangkatan calon jemaah haji yang dilakukan oleh PT. Djahidin Universal Tour dan upaya hukum yang dapat dilakukan calon jemaah haji atas gagalnya keberangkatan haji oleh PT. Djahidin Universal Tour Berdasarkan Undang-Undang Nomor 13 Tahun 2008 tentang penyelenggaraan ibadah haji dihubungkan dengan buku III KUH Perdata. Permasalahan di atas dianalsis dengan menggunakan spesifikasi penelitian melalui metode deskriptif analitis, metode pendekatan yuridis normatif, tahap penelitian melalui studi kepustakaan dan penelitian lapangan, teknik pengumpulan data melalui studi dokumen dan wawancara, serta metode analisis data melalui yuridis normatif kualitatif. Berdasarkan hasil analisis diperoleh kesimpulan bahwa akibat hukum biro perjalanan haji PT Djahidin Universal Tour terhadap calon jemaah haji yang gagal berangkat, sebagaimana diatur dalam Pasal 1236 dan 1246 KUH Perdata, PT. Djahidin Universal Tour harus bertanggungjawab mengembalikan seluruh biaya perjalanan haji beserta kerugiannya akibat dari kegagalan keberangkatan sesuai dengan kewajibannya atau memberikan prioritas pertama kepada calon jemaah haji yang gagal berangkat tersebut untuk diberangkatkan pada tahun berikutnya. Penyelesaian sengketa yang timbul dari kegagalan keberangkatan perjalanan haji, yaitu dapat diselesaikan dengan damai yakni musyawarah dan apabila belum tercapainya suatu kesepakatan antara kedua belah pihak, maka dapat diselesaikan di Pengadilan.
\end{abstract}

\section{Kata Kunci : Akibat Hukum, Wanprestasi, Ibadah Haji khusus}

Abstract- The failure to depart for prospective pilgrims regarding the non-fulfillment of obligations by the special pilgrimage travel agency is one form of default as the implementation of special pilgrimage tour by PT. Djahidin Universal Tour failing to dispatch prospective pilgrims. This agency must be responsible for compensation due to the failure to depart for prospective pilgrims. Legal effort can be undertaken by prospective pilgrims on the failure of pilgrimage departure by PT. Djahidin Universal Tour based on Law Number 13 Year 2008 concerning the Implementation of Hajj Pilgrimage connected with Book III of Civil Code. This study aimed at understanding 
legal consequences of the failure to depart for prospective pilgrims by PT. Djahidin Universal Tour and legal efforts for prospective pilgrims for its failure based on Law Number 13 Year 2008 concerning the implementation of pilgrimage connected with book III of Civil Code. The aforementioned problems were analyzed by using research specifications through descriptive-analytical method, normative juridical approach, research stages through literature study and field study, data collection techniques through document studies and interviews, and data analysis method through qualitative normative juridical method. The result reveals that the legal consequences of PT. Djahidin Universal Tour hajj travel agency against prospective pilgrims who failed to depart, as stipulated in Articles 1236 and 1246 of the Civil Code, PT. Djahidin Universal Tour must be responsible for returning all Hajj travel costs and their losses due to failure of departure in accordance with its obligations or giving priority to prospective pilgrims who failed to depart for performing Hajj in the following year departure. Settlement of disputes arising from the failure of the pilgrimage departure, which can be resolved peacefully through deliberation and if an agreement has not yet been reached between the two parties, then it can be resolved in the Court.

\section{Key Words : Legal Consequences, Default, Special Hajj}

\section{A. PENDAHULUAN}

\section{Latar Belakang}

Haji merupakan Rukun Islam yang kelima dimana pelaksaannya pada waktu tertentu yaitu antara tanggal 8 sampai dengan tanggal 13 Dzulhijjah setiap tahunnya. Rangkaian kegiatan manasik haji baik yang berupa rukun maupun wajib haji selurunya dilakukan di tempat-tempat yang telah ditetapkan oleh syariat agama, antara lain

Mekkah, Arafah, Mina dan Muzdalifah termasuk ziarah ke makam Nabi Muhammad SAW di Madinah di mana tempat-tempat tersebut berada di Kerajaan Arab Saudi. ${ }^{1}$

Penyelenggaraan ibadah haji merupakan tugas nasional karena jumlah jemaah haji Indonesia yang sangat besar, melibatkan berbagai instansi dan lembaga, baik dalam negeri maupun luar negeri, dan berkaitan dengan berbagai aspek, antara lain bimbingan, transportasi, kesehatan, akomodasi, dan keamanan. ${ }^{2}$

$$
\text { Antusiasme masyarakat }
$$

Indonesia untuk menunaikan ibadah haji dari tahun ketahun cenderung

\footnotetext{
${ }^{1}$ Ahmad Nidjam \& Alatief Hanan, Manajemen Haji, Jakarta: Zikrul Hakim, 2001. Hlm. 1.

${ }^{2}$ Anonim, Dinamika Perhajian, Direktorat Jenderal Penyelenggaraan Haji dan Umrah, Departemen Agama RI Jakarta, 2007.
} 
selalu meningkat hal ini mengakibatkan daftar tunggunyapun semakin panjang. Haji Plus atau yang sering dikenal dengan $\mathrm{ONH}$ Plus menjadi alternatif yang lebih diminati oleh para calon jamaah haji. ONH Plus diselenggarakan oleh BPU (Biro Perjalanan Umum) yang selanjutnya disebut Biro Perjalanan haji, ini termasuk program pemerintah yang pelaksaannya diselenggarakan oleh pihak swasta. ${ }^{3}$

Di satu sisi, penyelenggaraan ibadah haji khususnya yang dilaksanakan oleh pihak swasta banyak menuai permasalahan, salah satunya yaitu gagalnya pemberangkatan calon jemaah haji, yang menimbulkan kerugian bagi para calon jamaah haji. ${ }^{4}$ Kegagalan pemberangkatan calon jemaah haji berkenaan dengan tidak dipenuhinya kewajiban untuk berprestasi dalam suatu akad sebagai salah satu bentuk dari wanprestasi, selain dari

\footnotetext{
${ }^{3}$ Muchtar Adam, Cara Mudah Naik Haji, Bandung: Mizan, 1995. Hlm. 27.

${ }^{4}$ Wahyu, Solusi Kisruh Batalnya Haji oleh Pihak Swasta,http://www.indomedia.com, diakses tanggal 19 April 2017, Jam 20.19 WIB.
}

terlambat berprestasi dan/atau berprestasi tapi keliru. ${ }^{5}$

$$
\text { Dalam pelaksanaan }
$$

pemberangkatan calon Jemaah haji tersebut timbul persoalan dimana calon Jemaah haji tidak dapat diberangkatkan ke tanah suci Mekkah untuk melaksanakan ibadah haji karena ada salah satu yang tidak dapat diantisipasi sebelumnya oleh PT. Djahidin Universal Tour.

Berkenaan dengan gagalnya keberangkatan calon Jemaah haji oleh biro perjalanan haji PT. Djahidin Universal Tour, maka dihubungkan dengan Buku III BW, terdapat permasalahan dalam ruang lingkup hukum perjanjian, dalam hal ini terjadi wanprestasi dari pihak agen travel PT. Djahidin Universal Tour. Di satu sisi, perjanjian dibuat dalam bentuk tertulis, sehingga untuk permasalahan mengarah pada pertanggungjawaban agen travel tersebut.

\section{Identifikasi Masalah}

1. Bagaimana akibat hukum gagalnya keberangkatan calon jemaah haji yang

5 J. Satrio, Hukum Perikatan: Perikatan Pada Umumnya, Bandung: Alumni, 1993. HIm. 89-91. 


$\begin{array}{lrl}\text { dilakukan oleh PT. } & \text { dihubungkan dengan buku III } \\ \text { Djahidin Universal Tour } & \text { KUHPerdata. } \\ \begin{array}{l}\text { Berdasarkan Undang- } \\ \text { Undang No. } 13 \text { Tahun }\end{array} & \begin{array}{l}\text { 2. Upaya hukum yang dapat } \\ \text { dilakukan calon jemaah haji }\end{array} \\ \text { pentang } & \text { atas gagalnya keberangkatan } \\ \text { haji dihubungkan dengan } & \text { haji oleh PT. Djahidin } \\ \text { buku III KUH perdata? } & \text { Universal Tour Berdasarkan } \\ \text { Bagaimana upaya hukum } & \text { Undang-Undang No. 13 Tahun } \\ \text { yang dapat dilakukan } & \text { 2008 tentang penyelenggaraan } \\ \text { calon jemaah haji atas } & \text { ibadah haji dihubungkan }\end{array}$
gagalnya keberangkatan haji oleh PT. Djahidin Universal Tour Berdasarkan UndangUndang No. 13 Tahun 2008 tentang penyelenggaraan ibadah haji dihubungkan dengan buku III KUH perdata?

\section{Tujuan Penulisan}

Tujuan penelitian ini adalah untuk memahami:

1. Akibat hukum gagalnya keberangkatan calon jemaah haji yang dilakukan oleh PT. Djahidin Universal Tour Berdasarkan Undang-Undang No. 13 Tahun 2008 tentang penyelenggaraan ibadah haji

\section{Metode Penelitian}

Permasalahan di atas dianalsis dengan menggunakan spesifikasi penelitian melalui metode deskriptif analitis, metode pendekatan yuridis normatif, tahap penelitian melalui studi kepustakaan dan penelitian lapangan, teknik pengumpulan data melalui studi dokumen dan wawancara, serta metode analisis data melalui yuridis normatif kualitatif. 
B. HASIL DAN PEMBAHASAN

1. Akibat Hukum Gagalnya Keberangkatan Calon Jemaah Haji Yang Dilakukan Oleh PT. Djahidin Universal Tour

Hubungan antara biro penyelenggara Ibadah Haji Khusus dengan calon jamaah haji khusus didahului dengan perjanjian diantara para pihak, yang didalam perjanjian tersebut memuat syarat-syarat, hak, dan kewajiban para pihak. Perjanjian menurut Pasal 1313 BW adalah suatu perbuatan dengan mana satu orang atau lebih mengikatkan dirinya terhadap satu orang lain atau lebih, namun pengertian yang diberikan oleh BW belum sepenuhnya dapat memberikan penjelasan tentang makna perjanjian. ${ }^{6}$ Pengertian ini dinilai beberapa ahli hukum belumlah lengkap karena hanya menyebutkan kata "perbuatan" tanpa diketahui apakah perbuatan tersebut perbuatan hukum atau tidak. Perjanjian merupakan salah satu

${ }^{6}$ Abdulkadir Muhammad, Hukum Perdata Indonesia, Bandung: PT Citra Aditya Bakti, 2000. Hlm.198. sumber perikatan selain UndangUndang, hal ini diatur secara tegas dalam Pasal 1233 BW bahwa;

"tiap-tiap
perikatan
dilahirkan
baik karena
persetujuan
(perjanjian)
baik karena
Undang-
Undang."

Bentuk pertanggungjawaban yang didapatkan peneliti setelah melakukan penelitian di lapangan berdasarkan Undang-Undang Nomor 8 Tahun 1999 Tentang Perlindungan Konsumen yaitu selain mengajukan gugatan terhadap kelalaian biro perjalanan haji PT. Djahidin Universal Tours, ajaran hukum juga memperkenalkan calon jemaah haji untuk mengajukan gugatan atas wanprestasi. Tanggung jawab biro perjalanan haji PT. Djahidin Universal Tours yang dikenal dengan wanprestasi adalah tanggung jawab berdasarkan kontrak. Ketika suatu produk rusak dan mengakibatkan kerugian, calon jemaah haji khusus 
biasanya melihat isi kontrak atau perjanjian atau jaminan yang merupakan bagian dari kontrak, baik tertulis maupun lisan. ${ }^{7}$

Keuntungan bagi calon jemaah haji khusus dalam gugatan berdasarkan teori ini adalah penerapan kewajiban yang sifatnya mutlak, yaitu suatu kewajiban yang tidak didasarkan pada upaya yang telah dilakukan penjual untuk memenuhi janjinya. Itu berati apabila biro perjalanan haji PT. Djahidin Universal Tours telah berupaya memenuhi janjinya tetapi calon jemaah haji khusus tetap menderita kerugian, maka biro perjalanan haji PT. Djahidin Universal Tours tetap dibebani tanggung jawab untuk mengganti kerugian. Akan tetapi, di dalam prinsip tanggung jawab berdasarkan wanprestasi terdapat beberapa kelemahan yang dapat mengurangi bentuk perlindungan hukum terdapat kepentingan calon jemaah haji.

Berdasarkan Undang-Undang Nomor 13 Tahun 2008 Tentang

${ }^{7}$ Solahudin, Kitab Undang-Undang Hukum Perdata, Jakarta: Visimedia, 2008
Penyelenggaraan Ibadah Haji Pasal 64 (1) bahwa,

"Penyelengga

ra Ibadah

Haji Khusus

yang tidak

melaksanaka

$\mathrm{n}$ ketentuan

sebagaimana

dimaksud

dalam Pasal

40 dipidana

dengan

pidana

penjara

paling lama 6

(enam) tahun

dan/atau

denda paling

banyak

Rp1.000.000.

000,00 (satu

miliar

rupiah).

Akibat Hukum Gagalnya Keberangkatan Calon Jemaah Haji dari aspek hukum, tanggung jawab hukum PT. Djahidin Universal Tours dapat dilihat dari 3 (tiga) aspek, yaitu aspek perdata, pidana, dan 
administratif. Dari aspek perdata, PT. Djahidin Universal Tours telah melakukan wanprestasi tidak memberangkatkan calon jamaah haji, selain itu juga telah melakukan perbuatan melawan hukum (onrechmatige daad dalam Bahasa Belanda dan Tort dalam Bahasa Inggris). ${ }^{8}$

Oleh karena itu PT. Djahidin Universal Tours dapat dituntut secara perdata untuk memenuhi perikatan yaitu memberangkatkan calon jamaah untuk haji ke tanah suci. Pemenuhan kewajiban PT. Djahidin Universal Tours tersebut dapat diselenggarakan oleh Biro Perjalanan haji lainnya, namun atas biaya PT. Djahidin Universal Tours. Alternatif lainnya, PT. Djahidin Universal Tours dapat dituntut dengan pembatalan perikatan sehingga harus mengembalikan uang yang telah disetorkan oleh calon jamaah haji untuk berangkat ke tanah suci.

Tanggung jawab biro perjalanan haji PT. Djahidin Universal Tours terhadap calon

${ }^{8}$ M. Yahya Harahap, Segi-Segi Hukum Perjanjian, Bandung: Penerbit Alumni, 1986. Hlm. 6. jemaah haji yang gagal berangkat, sebagaimana diatur dalam KUHPerdata Pasal 1236 yang berbunyi;

"Debitur

wajib

memberi

ganti biaya,

kerugian dan

bunga kepada

kreditur bila

ia

menjadikan

dirinya tidak

mampu untuk

menyerahkan

barang itu

atau tidak

merawatnya

dengan

sebaik-

baiknya

untuk

menyelamatk

annya."

Dan dalam pasal

1246

berbunyi;

"Biaya, ganti

rugi dan

bunga, yang 
boleh dituntut

kreditur,

terdiri atas

kerugian

yang telah

dideritanya

dan

keuntungan

yang

sedianya

dapat

diperolehnya,

tanpa

mengurangi

pengecualian

dan

perubahan

yang disebut

di bawah

ini."

PT. Djahidin Universal Tours

harus mengembalikan seluruh biaya perjalanan haji beserta kerugiannya akibat dari kegagalan keberangkatan sesuai dengan kewajibannya atau memberikan prioritas pertama kepada calon jemaah haji yang gagal berangkat tersebut untuk diberangkatkan pada tahun berikutnya. Penyelesaian sengketa yang timbul dari kegagalan keberangkatan perjalanan haji, yaitu dapat menyelesaikannya melalui gugatan ke Badan Penyelesaian Sengketa Konsumen (BPSK) dengan jalan mediasi, konsiliasi dan arbitrase.

Dari aspek pidana, pertanggungjawaban pidana dapat dimintakan kepada PT. Djahidin Universal Tours karena dinilai telah melakukan kesalahan. Kesalahan merupakan hal yang sangat penting untuk mempidana seseorang karena di dalam hukum pidana dikenal asas "tiada pidana tanpa kesalahan (geen straf zonder schuld)". Terkait dengan hal ini, ada beberapa kesalahan atau tindak pidana yang diduga telah dilakukan oleh PT. Djahidin Universal Tours, yaitu:

1. Tindak pidana penggelapan (Pasal 372 KUHP).

2. Tindak pidana penipuan (Pasal 378 KUHP).

Dari aspek administratif, PT. Djahidin Universal Tours telah melakukan pelanggaran kebijakan atau ketentuan hukum administratif. 
PT. Djahidin Universal Tours harus dikenai sanksi administratif berupa pencabutan ijin operasional oleh Kementerian Agama Republik Indonesia. Dengan adanya pencabutan izin tersebut, PT. Djahidin Universal Tours tidak dapat menyelenggarakan ibadah haji lagi.

Sanksi Administratif yang harus didapat PT. Djahidin Universal Tours akibat gagalnya memberangkatkan haji dapat berupa:

1. Peringatan tertulis travel yang tidak melakukan kewajibannya yang tercantum dalam UndangUndang Nomor 13 Tahun 2008 Tentang Penyelenggaraan Ibadah Haji, diberi peringatan tertulis untuk tidak mengulangi lagi perbuatannya dalam pemberangkatan selanjutnya yang diatur dalam Peraturan

Pemerintah Nomor 79 Tahun 2012 Tentang Pelaksanaan UndangUndang Nomor 13 Tahun 2008.
2. Pembekuan izin operasional jika travel tersebut melakukan pelanggaran yang kedua kalinya yang mengakibatkan kerugian terhadap jamaah maka izin operasional travel tersebut dibekukan paling lama 2 tahun.

3. Pencabutan izin operasional jika travel tersebut masih melakukan pelanggaran maka izin operasional dari travel tersebut dicabut oleh menteri agama dan apabila izinnya merupakan izin biro perjalanan wisata maka akan dicabut oleh menteri yang membidangi pariwisata, gubernur,bupati/walikota. Menurut peneliti dasar hukum inilah yang membuat banyak travel yang melakukan kegiatan yang banyak merugikan masyarakat karena memiliki sanksi yang termasuk kategori ringan dan bisa saja ketika izin dicabut, maka yang 
membuat travel tersebut bisa saja membuat travel dengan nama yang lain dan menggunakan nama orang lain sebagai pemilik perusahaan tersebut selama pengelola yang dicabut izinnya tersebut tidak mendapat hukuman berupa kurungan atau sanksi sosial dari masyarakat Indonesia karena membuat sebuah Perseroan Terbatas (PT) tidak begitu mahal, kisaran harga 13 juta sebuah PT bisa terbentuk dan kembali membodohi jamaah.

Upaya Hukum Yang Dapat Dilakukan Calon Jemaah Haji Atas Gagalnya Keberangkatan

\section{Haji Oleh PT. Djahidin Universal}

Bentuk upaya hukum bagi jamaah haji khusus yang mengalami kegagalan keberangkatan adalah dengan pemerintah melakukan perlindungan hukum preventif berupa adanya peraturan yang melindungi jamaah calon jemaah haji ketika terdapat penyimpangan yang dilakukan pelaku usaha dan perlindungan hukum represif dengan memberikan sanksi ketika ada penyimpangan yang dilakukan oleh pelaku usaha.
Sanksi-sanksi yang diberikan kepada pelaku usaha tersebut termaktub dalam pasal 51 Peraturan Pemerintah Nomor 79 Tahun 2012 tentang Peraturan pelaksana UndangUndang Nomor 13 Tahun 2008 Tentang Penyelenggaraan Ibadah Haji, yaitu penyelenggara perjalanan ibadah haji khusus yang tidak dapat melaksanakan kewajibannya diberikan sanksi administrasi oleh menteri berupa peringatan tertulis, pembekuan izin penyelenggaraan atau pencabutan izin penyelenggaraan. Dalam teori perlindungan konsumen the social cost view of the manufacturer's duties, teori ini menekankan pada kewajiban pelaku usaha bisnis atau produsen untuk memberikan ganti rugi terhadap kerugian yang dialami oleh konsumen akibat produk/jasa yang digunakan. ${ }^{9}$

Berdasarkan hasil analisis peneliti terhadap Pasal 18 UndangUndang Nomor 8 Tahun 1999 tentang Perlindungan Konsumen mengenai perjanjian baku yang disepakati antara biro perjalanan haji

\footnotetext{
${ }^{9}$ Shidarta, Hukum Perlindungan Konsumen Indonesia, Jakarta: PT Grasindo, 2000. Hlm. 59.
} 
dengan calon jemaah haji terdapat fakta bahwa perjanjian baku tersebut bisa dilaksanakan namun, karena konsep perjanjiannya terlalu sederhana, melihat produk perjalanan jasa yang diperjanjian memiliki cakupan hukum yang luas. Perjanjian baku tersebut tidak ada mengatur mengenai teknis perjalanan, mulai dari detail administrasi dan keadaan yang bisa terjadi di lapangan pada saat pelaksanaan, termasuk juga bagaimana proses sengketa apabila terjadi. Jika ditinjau dari UndangUndang perlindungan Konsumen, sebenarnya perjanjian baku tersebut belum bisa dikatakan suatu perjanjian dan seharusnya ada perjanjian ikutan atau tambahan. Perjanjian di awal kesepakatan hanya sebagai perjanjian induk saja. ${ }^{10}$

Berdasarkan akibat hukum yang timbul itu maka Calon Jemaah Haji Khusus yang merasa dirugikan terhadap pelayanan Penyelenggara Ibadah Haji Khusus bisa mengajukan tuntutan terkait dengan kerugian yang mereka derita melalui media apapun dan itu memiliki

\footnotetext{
${ }^{10}$ Zulham, Hukum Perlindungan Konsumen,
} Jakarta: Kencana, 2013. Hlm. 83. pertanggungjawaban yang sudah dijamin didalam hukum di Indonesia. $^{11}$

Pertanggungjawaban tersebut juga bisa dilaksanakan melalui aspek hukum perdata berupa ganti kerugian yang diderita dan diperhitungkan, dan bisa juga melalui aspek hukum pidana yang bisa diarahkan ke penggelapan dana perjalanan haji khusus.

hal ini berdasarkan KUHperdata pasal 1365 , pasal 1366 , dan pasal 1367.

\section{Pasal 1365 KUHPerdata} berbunyi;
"Tiap
perbuatan
melanggar
hukum yang
membawa
kerugian
kepada orang
lain,
mewajibkan
orang yang
karena
salahnya
menerbitkan

\footnotetext{
${ }^{11}$ Djaja S. Meliala, Hukum Perdata Dalam Perspektif BW, Bandung: Nuansa Aulia,2014. Hlm. 177.
} 


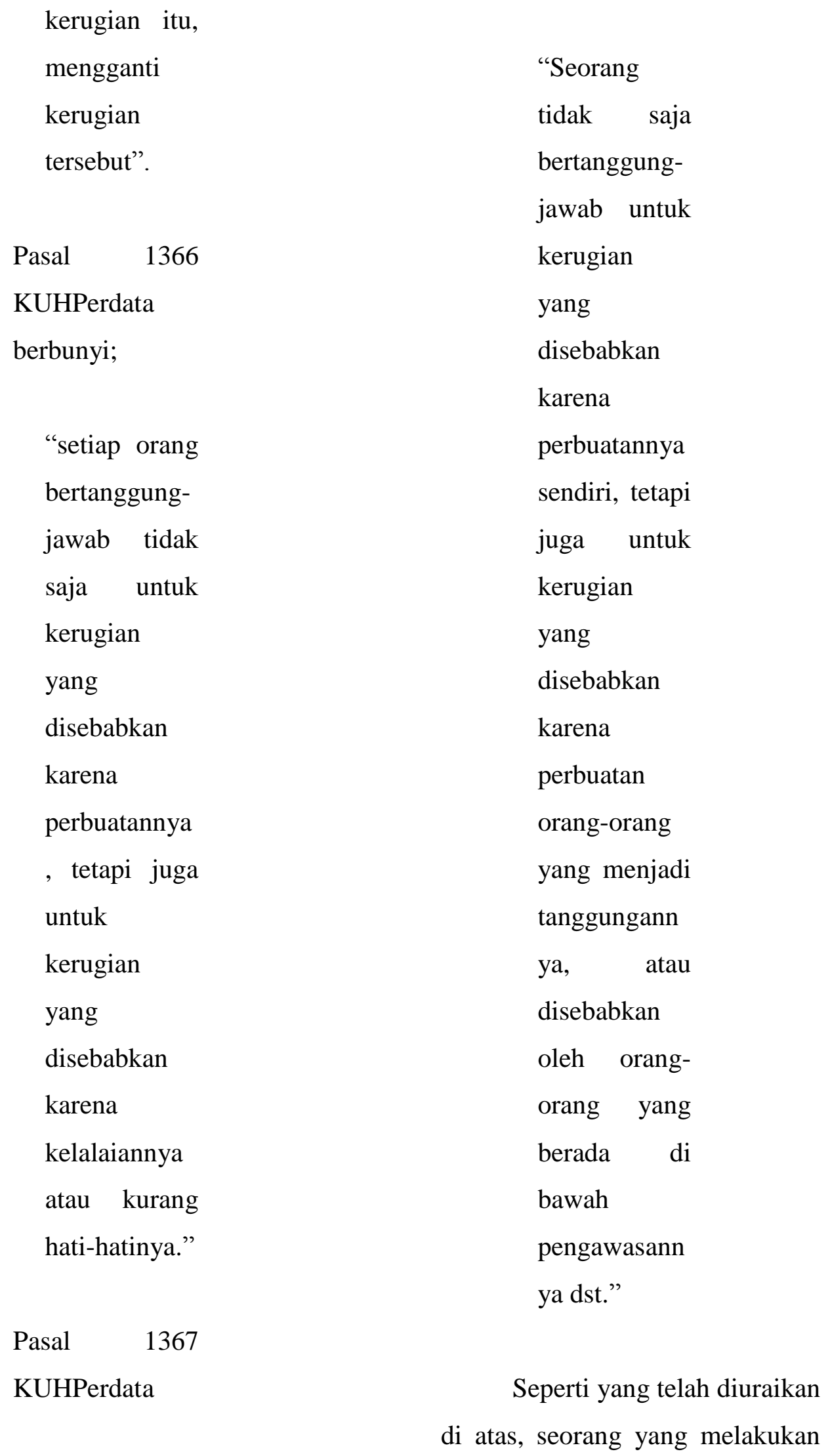




\begin{abstract}
perbuatan melawan hukum maupun wanprestasi wajib mengganti kerugian. Untuk itu perlu lebih memahami mengenai tuntutan-tuntutan apa yang dimungkinkan dalam perbuatan melawan hukum maupun wanprestasi. Terlebih dahulu akan membahas mengenai tuntutan dalam perbuatan melawan hukum.
\end{abstract} Dalam pasal 1365 KUHPerdata memberikan kemungkinan beberapa jenis penuntutan, antara lain:

1. Ganti kerugian atas kerugian dalam bentuk uang;

2. ganti kerugian dalam bentuk natura atau pengembalian keadaan pada keadaan semula;

3. pernyataan bahwa perbuatan yang dilakukan dalah bersifat melawan hukum;

4. larangan untuk melakukan suatu perbuatan;

5. meniadakan sesuatu yang diadakan secara melawan hukum;
6. pengumuman daripada keputusan atau dari sesuatu yang telah diperbaiki.

Mengenai Penyelesaian Sengketa diatur pada BAB X Undang-Undang Nomor 8 Tahun 1999 tentang Perlindungan Konsumen. Adapun upaya hukum yang dimaksud antara lain:

1. Penyelesaian sengketa melalui Badan Penyelesaian Sengketa Konsumen atau Pengadilan;

a. Badan Penyelesaian Sengketa Konsumen Diatur pada Bab XI Pasal 49 - 52 UndangUndang Nomor 8 Tahun 1999 tentang Perlindungan Konsumen. Cara konsumen adalah mengajukan pengaduan tertulis maupun tidak tertulis tentang terjadinya pelanggaran tanpa diperlukan persetujuan dari pelaku usaha. Namun, BPSK dapat menolak jika telah diatur kesepakatan dalam 


\author{
perjanjian penyelesaian \\ sengketa melalui forum \\ lainnya. \\ b. Pengadilan
}

Diatur pada Pasal
$47 \quad$ Undang-Undang
Nomor 8 Tahun 1999
tentang Perlindungan
Konsumen. Dalam hal ini
mengacu
tentangketentuan
Peradilan Umum dengan
cara konsumen
mengajukan Gugatan
dengan syarat-syarat
dilakukan oleh :
1) Seorang konsumen
yang dirugikan atau
ahli waris yang
bersangkutan;
2) Kelompok
konsumen yang
mempunyai
kepentingan yang
sama;
3) Lembaga
perlindungan
konsumen swadaya
maitu

badan hukum atau

yayasan, yang

dalam anggaran

dasarnya

menyebutkan

dengan tegas

bahwa tujuan

didirikannya

organisasi tersebut

adalah untuk

kepentingan

perlindungan

konsumen dan

telah melaksanakan

kegiatan

sesuaidengan

anggaran dasarnya;

4) Pemerintah

dan/atau instansi

terkait apabila

barang dan/atau

jasa yang

dikonsumsi atau

dimanfaatkan

mengakibatkan

kerugian materi

yang besar dan/atau

korban yang

meskipun

demikian, Pasal 45

Undang-Undang 


Nomor 8 Tahun
1999 tentang
Perlindungan
Konsumen dalam
Penjelasannya
menerangkan
bahwa dalam
penyelesaian
sengketa tidak
menutup
kemungkinan
untuk penyelesaian
secara damai tanpa
melalui $\quad$ Badan
Penyelesaian
Sengketa
Konsumen atau
Pengadilan
sepanjang tidak
bertentangan
dengan Undang-
Undang Nomor 8
Tahun
tentang
Perlindungan
Konsumen.

2. Penyelesaian sengketa di luar Pengadilan.

$$
\begin{aligned}
& \text { Pada prinsipnya } \\
& \text { penyelesaian sengketa di } \\
& \text { luar Pengadilan adalah }
\end{aligned}
$$

berdasarkan kesepakatan

dari Pelaku Usaha dan

Konsumen mengenai bentuk

dan besarnya ganti rugi

dan/atau mengenai tindakan

tertentu untuk menjamin

tidak akan terjadi kembali

atau tidak akan terulang

kembali kerugian yang

diderita oleh konsumen

(Pasal 47 Undang-Undang

Nomor 8 Tahun 1999

tentang Perlindungan

Konsumen).Jaminan yang

dimaksud diterangkan oleh

Penjelasan Pasal 47

berupa pernyataan

tertulis yang menerangkan

bahwa tidak akan

terulang kembali perbuatan

yang merugikan konsumen.

Berdasarkan hal-hal diatas maka perlindungan konsumen terhadap Calon Jemaah Haji yang gagal berangkat haji adalah mendahulukan penyelesaian sengketa di luar Peradilan. Dalam hal ini Biro Perjalanan Haji harus menunjukan itikad baik untuk memberikan jaminan akan menyelesaikan semua ganti rugi 
atau kompensasi sesuai yang diperintahkan Undang-Undang Nomor 8 Tahun 1999 tentang Perlindungan Konsumen. Apabila tidak ada itikad baik, dan tidak ada kesepakatan kedua belah pihak calon jemaah haji dapat melakukan upaya hukum melalui Badan Penyelesaian Sengketa Konsumen (non litigasi) ataupun melalui jalur Pengadilan (litigasi)

\section{PENUTUP}

\section{Simpulan}

1. Gagalnya keberangkatan ibadah haji yang dilakukan sepihak oleh biro perjalanan haji PT. Djahidin Universal Tour memberikan kerugian terhadap calon Jemaah haji baik secara materil maupun immateril.

Bentuk pertanggungjawaban hukum oleh PT. Djahidin Universal Tour selaku biro perjalanan ibadah haji khusus adalah dengan cara mengembalikan seluruh biaya haji khusus beserta kerugiannya akibat dari kegagalan keberangkatan jemaah haji khusus tersebut sesuai dengan apa yang tertuang dalam kontrak yang telah disepakati bersama atau memberikan prioritas pertama kepada calon jemaah haji yang gagal berangkat tersebut untuk diberangkatkan pada tahun berikutnya.

2. Upaya hukum terhadap pemakai jasa biro perjalanan haji khusus akibat gagalnya keberangkatan calon jamaah harus mendapatkan hak-haknya sesuai dengan KUHPerdata (BW), ketentuan Pasal 4 Undang-Undang Nomor 8 Tahun $1999 \quad$ Tentang Perlindungan Konsumen dan Undang-Undang Nomor 13 Tahun 2008 tentang Penyelenggaraan Ibadah Haji adalah pemberian ganti rugi terhadap pihak yang dirugikan dalam hal ini adalah calon jemaah haji. Upaya hukum yang dilakukan oleh calon jemaah haji dapat diselesaikan melalui jalur diluar pengadilan (non litigasi) secara damai yakni musyawarah dan apabila tidak tercapainya suatu kesepakatan antara kedua belah pihak, maka dapat diselesaikan di Pengadilan (litigasi). 


\section{Saran}

1. Pemerintah Republik Indonesia dalam penyelenggaraan ibadah haji khusus harus lebih tegas dalam menegakkan peraturan yang terkait dengan sistem penyelenggaraan ibadah haji khusus, karena sanksi yang ada saat ini hanya sanksi administrasi yang bahkan sampai 3 kali pelanggaran baru terjadi pencabutan izin operasional.

2. Pengelola travel yang bermasalah seharusnya didata agar ketika pelaku usaha ingin membuat sebuah perusahaan lagi dibidang travel haji khusus maka akan ketahuan dan bisa diberikan sanksi kembali. Sedangkan Travel yang memiliki izin operasional dan terpecaya seharusnya dipromosikan atau disosialisasikan oleh kementerian agama disemua tingkatan agar masyarakat tidak tertipu lagi dengan banyaknya travel nakal yang beroperasi.

3. Ibadah haji merupakan ibadah wajib bagi yang telah memenuhi syarat dan tidak membebani calon jamaah. Bagi calon jamaah haji jangan mudah terpengaruh dengan program-program travel haji khusus yang belum jelas kebenarannya. Jika calon jemaah haji belum mampu melaksanakan ibadah haji jangan memaksakan diri untuk pergi ke tanah suci.

\section{DAFTAR PUSTAKA}

\section{Buku}

Abdulkadir Muhammad, Hukum Perusahaan Indonesia, Bandung: Citra Aditya Bakti, 2010.

Ahmad Nidjam \& Alatief Hanan, Manajemen Haji, Jakarta: Zikrul Hakim, 2001.

Djaja S. Meliala, Hukum Perdata Dalam Perspektif BW, Bandung: Nuansa Aulia,2014.

J. Satrio, Hukum Perikatan: Perikatan Pada Umumnya, Bandung: Alumni, 1993.

Muchtar Adam, Cara Mudah Naik Haji, Bandung: Mizan, 1995. 
M. Yahya Harahap, Segi-Segi Hukum

Perjanjian, Bandung: Penerbit Alumni, 1986

Shidarta, Hukum Perlindungan Konsumen Indonesia, Jakarta: PT Grasindo, 2000.

Solahudin, Kitab Undang-Undang Hukum Perdata, Jakarta: Visimedia, 2008

Zulham, Hukum Perlindungan Konsumen, Jakarta: Kencana, 2013.

\section{Internet}

Anonim, Dinamika Perhajian,

Direktorat Jenderal

Penyelenggaraan Haji dan

Umrah, Departemen Agama RI Jakarta, 2007.
Wahyu, Solusi Kisruh Batalnya Haji oleh Pihak Swasta, http://www.indomedia.com, diakses tanggal 19 April 2017, Jam 20.19 WIB.

\section{Peraturan Perundang-undangan}

Undang-Undang Dasar 1945.

Kitab Undang-Undang Hukum Perdata (BW).

Undang-Undang Nomor 8 Tahun 1999 Tentang Perlindungan Konsumen.

Undang-Undang Republik Indonesia Nomor 12 Tahun 2006 Tentang Kewarganegaraan Republik Indonesia

Undang-Undang Nomor 40 Tahun 2007 tentang Perseroan Terbatas. Undang-Undang Nomor 13 Tahun 2008 Tentang Penyelenggaraan Ibadah Haji. 